Анатолий Николаевич Щукин. - М. : Астрель АСТ: Хранитель, 2007. - 746 с. 11. Яковлев В. Ю. Ценностно-смысловые основания научного познания : автореф. дис. на соискание уч. степени док. филос. наук : 09.00.01 / В. Ю. Яковлев. - Киров, 2009. - 47 с.

\title{
ЗМІСТ ПСИХОЛОГО-ПЕДАГОГІЧНОЇ ПІДГОТОВКИ МАЙБУТНЬОГО ВИКЛАДАЧА ДО ПРОФЕСІЙНОЇ ТВОРЧОЇ ДІЯЛЬНОСТІ
}

Сгадова В. В. Зміст психолого-педагогічної підготовки майбутнього викладача до професійної творчої діяльності.

У статті розглянуто зміст психолого-педагогічної підготовки майбутнього викладача до професійної творчої діяльності, висвітлено різні види навчальної діяльності студентів, які забезпечують формування в них творчих умінь.

Ключові слова: методологічні, теоретичні, методичні й технологічні знання, творчі вміння, умови здійснення психолого-педагогічної підготовки студентів до творчої діяльності.

Сгадова В. В. Содержание психолого-педагогической подготовки будущего преподавателя к профессиональной творческой деятельности.

В статье рассмотрено содержание психолого-педагогической подготовки будущего преподавателя к профессиональной творческой деятельности, освещены различные виды учебной деятельности студентов, которые обеспечивают формирование у них творческих умений.

Ключевые слова: методологические, теоретические, методические и технологические знания, творческие умения, условия осуществления психолого-педагогической подготовки студентов к творческой деятельности.

Sgadova V. V. The content of future lecturer psychology-pedagogical preparation to professional creative activity.

The content of psychology-pedagogical preparation of future lecturers to professional creative activity is analyzed. Different forms of students' educational activity which develop their creative skills are highlighted.

Key words: methodological, theoretical, methodical and technological knowledge, creative skills, conditions providing psychology-pedagogical preparation of students to professional creative activity.

Зміни, що відбуваються в сучасному суспільстві, потребують переорієнтації освіти як на творчий розвиток особистості, так і на підготовку майбутніх викладачів до його здійснення. Ось чому в умовах розбудови національної системи освіти актуальною є проблема підготовки викладача як особистості, що характеризується широкою ерудицією, високою професійною майстерністю, творчим підходом до організації навчально-виховного процесу. У методичному аспекті підготовка майбутніх викладачів охоплює формування емоційноціннісного ставлення до творчого процесу, опанування студентами знань і вмінь, пов'язаних 3 організацією творчого пошуку, педагогічного експерименту, запровадження інновацій у практику вищої школи.

Питання педагогічної творчості та творчого потенціалу досліджується у працях А. Алексюка, В. Бондаря, В. Буряка, Є. Бондаревської, В. Кан-Калика, А. Капської, Н. Кичук, М. Нікандрова, Я. Пономарьова, Н. Тализіної, О. Хижної.

Психолого-педагогічні аспекти проблеми, що розглядаються, знайшли відображення в публікаціях К. Гуревича, В. Зінченка, Л. Кондрашової, В. Мадзігона, Ю. Мальованого, С. Максименка, П. М'ясоїда, О. Павлютенкова, О. Савченко, Н. Токара, Р. Хмелюк, Б. Федоришина, М. Янцура. Методології педагогічних досліджень присвячено роботи 
Ю. Бабанського, М. Болдирева, Г. Воробйова, С. Гончаренка, М. Данілова, В. Журавльова, В. Загвязінського, В. Раєвського, М. Скаткіна, В. Черепанова та ін.

Науково-дослідну діяльність студентів, як елемент підготовки майбутніх фахівців, розглядають Р. Горохова, А. Кочетова, В. Савченко, Р. Сеульський, Т. Торгашина, Н. Яковлєва, наукову діяльність педагогічних ВНЗ - В. Андреєв, В. Безпалько, В. Моляко, В. Успенський та ін.

Із дисертаційних досліджень останніх років, у яких розглядається окреслена проблема, слід назвати праці Л. Ройко, С. Тезикової, В. Федяєвої, І. Бичкової, Л. Машкіної. Проте, зазначені дослідження стосуються головним чином загальноосвітньої школи та довишівського етапу підготовки педагогічних кадрів у системі непереривної освіти. Що ж до підготовки майбутніх викладачів до творчої дослідницької діяльності, то наукові доробки в цьому напрямі фактично відсутні. Водночас підвищення рівня наукової компетентності викладачів, що визначається зростаючими вимогами сучасної вищої школи, актуалізує дослідження цієї проблеми.

Вивчення наукових джерел свідчить, що в процесі професійно-педагогічної підготовки студентів у вищих навчальних закладах у них має бути сформована особлива педагогічна свідомість, яка, з одного боку, давала б їм змогу виявляти творчу активність як суб'єктів пізнання, моделювання, спілкування (І. Зязюн, Н. Кічук, Н. Кузьміна), особистісно професійного самопізнання, самопроектування, саморегулювання i саморозвитку (Т. Осадча, О. Пєхота), а 3 іншого - як менеджера навчально-пізнавального процесу (В. Бондар, В. Крижко, Є. Павлютенков). Така ситуація зумовлює потребу спеціально готувати студентів до інноваційного педагогічного менеджменту як сукупності принципів, методів і засобів управління навчально-пізнавальною діяльністю учнів.

Метою статті є розкриття змісту психолого-педагогічної підготовки майбутнього викладача до професійної творчої діяльності.

Майбутній педагог зможе успішно організовувати навчально-виховний процес, якщо матиме необхідні знання про предмет своєї діяльності, способи, засоби і прийоми творчого розв'язання педагогічних завдань.

Дослідженню системи професійних знань педагога присвячено праці О. Абдуліної, Н. Кузьміної, О. Мороза, М. Скаткіна, В. Сластьоніна та інших, у яких виокремлено такі компоненти системи знань: методологічні, теоретичні, практичні (Н. Кузьміна, М. Скаткін, В. Сластьонін); науково-теоретичні, конструктивно-технічні та нормативні, що регулюють діяльність педагога (В. Краєвський); фундаментальні та інструментальні (С. Архангельський).

На нашу думку, зміст підготовки майбутнього педагога до професійної творчої діяльності повинен містити чотири компоненти, а саме: методологічні, теоретичні, методичні й технологічні знання. Зумовлено це тим, що в сучасних умовах педагог зобов'язаний не тільки систематично поповнювати свої знання, а й здійснювати творчу науково-дослідницьку діяльність.

Дослідження I. Колеснікової підтверджують, що нині характер проблем зміщується 3 прикладного рівня до рівня теоретико-методологічного, коли неможливо прийняти педагогічне рішення без цілісного теоретико-методологічного його осмислення. Тільки володіння методологією наукового пізнання, теорією і технологією професійної творчості дає можливість педагогові розв'язати ці проблеми, бо знання про знання й методи пізнання забезпечують усвідомлене засвоєння і систематизацію знань (Л. Зоріна); рівень методологічних знань впливає на формування в педагога теоретичного мислення, що виявляється в упорядкованому творчому пошуку, чіткості формулювання завдань і мети, обгрунтованості висновків; знання про знання виконують роль евристик у процесі розв'язання професійно-педагогічних завдань.

У визначенні структури методологічних знань ми поділяємо думку дослідників, які зводять їх до знання не лише науково-дослідницької процедури, а й основ філософії i педагогіки. Ця структура тісно пов'язана 3 внутрішньою рефлексією, із методикою i 
логікою здійснення діяльності й аналітико-конструктивною, контрольно-оцінювальною функціями щодо власної діяльності (В. Андреєв, І. Ісаєв, В. Сластьонін).

Теоретико-методичні знання, 3 одного боку, істотно впливають на усвідомленість, цілеспрямованість творчості в діяльності особистості (О. Абдуліна [1], В. Сластьонін [6]), а 3 іншого - $є$ будівельним матеріалом, на основі якого здійснюється творча діяльність. Причому в педагога формується особливий стан готовності до мобілізації раніше набутих і до засвоєння нових теоретико-методичних знань, необхідних для творчого розв'язання професійних завдань (Н. Кузьміна) [5].

Теоретико-методичні знання, як стверджує В. Сластьонін, значною мірою сприяють розвитку творчого мислення, якщо педагог володіє не окремими розрізненими знаннями, а ïx системою, яка відображає структуру сучасного науково-педагогічного знання i здійснюється на основі сучасних наукових теорій, ідей, принципів [6]. Отже, віднесення теоретичних і методичних знань до змісту навчання потрібне для ефективної підготовки майбутнього педагога до творчої діяльності.

В. Безпалько, В. Бондар, I. Ісаєв, В. Сластьонін та інші науковці обгрунтували доцільність уведення до змісту освіти майбутніх педагогів технологічних знань, що є тим ланцюжком, який поєднує педагогічну теорію і практику, тісно пов'язану з педагогічною майстерністю i педагогічною творчістю. На їхню думку, практична спрямованість педагогічної технології забезпечує наукове обгрунтування і творчий підхід педагога до практики навчання, тобто побудову вчителем системи науково обгрунтованих дій, що передбачають:

а) чітке визначення цілей навчання;

б) добір відповідного змісту, методів і засобів навчання, а також форм організації навчального процесу;

в) використання методів аналізу й оцінки досягнення результатів $[3 ; 4 ; 6]$.

Аналіз наукової літератури та вивчення досвіду творчої діяльності вчителів дає можливість виокремити зміст методологічного, теоретичного, методичного i технологічного компонентів. Зокрема, методологічний компонент вміщує: знання загальних законів і категорій діалектики, законів розвитку, філософське розуміння проблеми особистості; знання загальної методології пізнання i творчості, загальнонаукових і часткових методів пізнання і творчості; знання методологічних основ

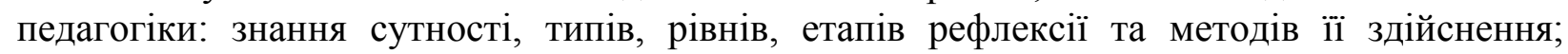
теоретичний: знання загальних основ педагогіки, теорії цілісного педагогічного процесу, теорії навчання й освіти; знання теорії педагогічної творчості, закономірностей, принципів і методів творчого саморозвитку особистості; методичний: знання загальної теорії і методики навчання відповідного предмета; знання сучасних концепцій і моделей навчання; технологічний: знання технологій конструювання i технології здійснення навчального процесу; знання часткових технологій, наприклад, технології діагностики навчання; знання технології розв'язання конкретних педагогічних завдань.

Формою реалізації теоретичної готовності майбутніх викладачів є діяльність, що потребує вияву ними відповідних умінь. Незважаючи на різні підходи до визначення педагогічних умінь, зазначимо, що в їх основу покладено відповідну теоретичну підготовку i врахування специфіки тієї навчальної діяльності, у якій ці вміння виявляються. У контексті нашого дослідження під уміннями розуміємо володіння способами і прийомами навчання та виховання, яке грунтується на використанні психолого-педагогічних i методичних знань i дає змогу студентам - майбутнім викладачам проникати в сутність педагогічної проблеми.

До вмінь професійної творчої діяльності викладача відносимо такі:

1) уміння, що відповідають етапам творчої діяльності: уміння бачити (виокремлювати) педагогічну проблему; знаходити іiі розв'язання; уміння генерувати ідеї; розробляти концепцію творчого пошуку; реалізовувати розроблену стратегію розв'язання проблеми; перевіряти розв'язання педагогічної проблеми; 
2) уміння використовувати методи наукових досліджень;

3) уміння здійснювати рефлексію творчої діяльності;

4) уміння теоретично узагальнювати i науково оформляти результати творчих досягнень: уміння конкретизувати, систематизувати і класифікувати фактичний матеріал; подавати науковий результат у формі статті, доповіді, методичної розробки.

У психолого-педагогічній літературі розглядаються різні види навчальної діяльності, які забезпечують формування в студентів відповідних умінь. У системі вищої освіти до таких видів відносять навчально-пізнавальну діяльність студента, науково-дослідницьку й виробничу практику (О. Абдуліна, Н. Кузьміна, В. Сластьонін та ін.).

У процесі спеціально організованої пізнавальної діяльності студентів залучають до вивчення нових педагогічних ідей, теорій і технологій, знайомлять на курсах і спецкурсах 3 педагогіки і психології 3 новітніми досягненнями педагогічної науки, сучасними педагогічними проблемами і суперечностями в освіті, навчають аналізувати і критично оцінювати різні точки зору на розв'язання тієї чи тієї педагогічної проблеми, моделювати професійні дії, здійснювати самоаналіз і самооцінку своєї професійної діяльності. Вони засвоюють теоретичні, методичні й технологічні знання, удосконалюють професійні вміння, а також такі творчі вміння, як: бачити педагогічну проблему; формулювати гіпотезу; визначати адекватні методи наукового дослідження; рефлексувати.

У ході науково-дослідницької діяльності (написання статей, магістерської та дипломної робіт) студенти оволодівають теорією творчості й технологією науково-педагогічного дослідження. Вони збагачуються теоретичними, методичними й технологічними знаннями, оволодівають творчими вміннями, зокрема, розробляти методологію наукового дослідження, реалізовувати його методику в своїй пошуковій діяльності, здійснювати рефлексію на кожному етапі діяльності, використовувати наукові методи дослідження.

Важливою умовою здійснення ефективної підготовки студентів до творчої діяльності $\epsilon$ добір адекватної технології навчання, цілісність якої забезпечується розробленням i використанням трьох їі компонентів: організаційних форм, методів і засобів навчання.

Серед різноманітних засобів навчання найважливішим є педагогічне завдання як спосіб визначення мети навчання, а також його активізації, управління, організації і діагностики.

Педагогічні ситуації, або завдання, є основним засобом підготовки вчителя до професійної діяльності. Їх досліджено у працях Ю. Кулюткіна, І. Лернера, В. Сластьоніна та інших науковців, які вважають, що навчити творчої діяльності можна лише через практичне розв'язання завдань.

На нашу думку, використання педагогічного завдання як засобу підготовки студентів до професійної творчості дає змогу надати навчанню особистісно зорієнтованої спрямованості, адже вони вводяться в спеціально створену або реально існуючу педагогічну ситуацію, з іншого боку, - забезпечують технологічність процесу внаслідок представлення змісту підготовки як системи спеціально сконструйованих завдань.

У науковій літературі існує значна кількість класифікацій педагогічних завдань. Доведено, що в основу системи педагогічних знань покладено три класифікації, які відповідають трьом рівням розвитку творчого мислення людини:

1) система знань - система завдань (І. Лернер, Н. Яковлєва);

2) методи пізнавальної діяльності - система завдань (I. Лернер та ін.);

3) інтелектуально-творчі якості особистості - система завдань (В. Андреєв) [2].

Об'єднуючи ці три рівні, можна класифікувати завдання, що забезпечить взаємозв'язок знань, умінь та інтелектуально-творчих якостей особистості. Зокрема, такими можуть бути завдання: на конструювання ситуації; виявлення або формулювання актуальної педагогічної проблеми; із недостатньою вихідною інформацією; на пошук необхідної інформації; на діагностику вихідного стану педагогічного об'єкта; пошук конструктивного розв'язання педагогічної проблеми; визначення мети, прийняття рішення, стратегії діяльності; на вивчення способів і прийомів перенесення педагогічного досвіду в інші умови; висунення гіпотез, уточнення умов, корекцію мети та алгоритму 
розв'язання педагогічної проблеми; на добір оптимальних педагогічних технологій; виявлення помилок; модернізацію змістових і технологічних аспектів професійної діяльності; на прогнозування перспектив запропонованого розв'язання; добір критеріїв аналізу й оцінки педагогічних явищ і процесів; аналіз і оцінку різних точок зору 3 конкретних проблем; оволодіння теоретичними й емпіричними методами наукових досліджень.

У вищій школі нині використовуються різноманітні організаційні форми і методи підготовки студентів до майбутньої творчої діяльності, а саме: моделювання, мікродослідження, метод проектів, аналіз конкретних ситуацій, ділові та рольові ігри, «мозковий штурм», дискусія, тренінг. Практика свідчить, що ці форми й методи активного навчання студентів сприяють розвитку творчих здібностей, вияву їхньої творчої активності.

Отже, педагогічна творчість - це активна професійна діяльність викладача, спрямована на пошук ефективних форм і методів навчання учнів (студентів), розвиток їхніх творчих можливостей, а також важлива умова становлення педагога, його самопізнання i самореалізації як особистості.

Характерними ознаками творчої діяльності $є$ :

а) наявність суперечності, проблемної ситуації чи творчого завдання;

б) соціальна й особистісна значущість творчої діяльності;

в) наявність об'єктивних (соціальних і матеріальних) передумов для творчості;

г) наявність суб'єктивних (особистісних) якостей - знань, умінь, позитивної мотивації, творчих здібностей особистості;

д) новизна й оригінальність процесу або результату.

Для зростання творчої індивідуальності педагога потрібні такі умови: стимулювання процесу осмислення власної індивідуальності; створення ситуацій, які потребували б застосування не тільки професійних умінь, а й якостей творчої індивідуальності.

Реалізація в навчальному процесі системного, особистісно зорієнтованого, технологічного й інноваційного підходів значною мірою сприяє ефективній підготовці майбутнього викладача до творчої професійної діяльності.

Підготовка майбутніх педагогів до професійної творчої діяльності $\epsilon$ складною педагогічною системою, якість і ефективність якої залежить від мети і засобів іiі досягнення. Готовність до професійної творчої діяльності ми розглядаємо як якість особистості, що динамічно розвивається, як систему, що інтегрує в собі мотиваційний, креативний, змістово-операціональний i рефлексивний компоненти. Перспективу подальших досліджень цієї проблеми вбачаємо у розробленні методики формування в майбутніх викладачів готовності до професійної творчої діяльності.

\section{Література}

1. Абдуллина О. А. Общепедагогическая подготовка учителя / О. А. Абдуллина. - М. Просвещение, 1990. - 141 с. 2. Андреев В. И. Педагогика творческого саморазвития / В. И. Андреев. - Казань, 1989. - 223 с. З. Беспалько В. П. Слагаемые педагогической технологии / В. П. Беспалько. - М. : Педагогика, 1989. - 192 с. 4. Бондар В. І. Дидактика : [підручник] / В. І. Бондар. - К. : Либідь, 2005. - 264 с. 5. Кузьмина Н. В. Профессионализм личности преподавателя и мастера производственного обучения / Н. В. Кузьмина. - М. : Высш. школа, 1990. - 119 с. 6. Сластенин В.А. Формирование личности учителя советской школы в процессе профессиональной подготовки / В. А. Сластенин. - М. : Просвещение, 1976. - 160 с. 